\title{
Response of bio-regulators to yield and quality of Indian mustard (Brassica juncea L. Czernj. and Cosson) under different irrigation environments
}

\author{
R. K. Dadhich ${ }^{1}$, R. S. Meena ${ }^{2 *}$, M. L. Reager $^{3}$ and B. C. Kansotia ${ }^{3}$ \\ ${ }^{1}$ National Seeds Corporation Limited, Sri Ganganagar- 335001 (Rajasthan), INDIA \\ ${ }^{2}$ Department of Agronomy Institute of Agricultural Sciences, Banaras Hindu University Varanasi -221 005 (U.P.), \\ INDIA \\ ${ }^{3}$ Swami Keswanand Rajasthan Agricultural University, Bikaner-334 006 (Rajasthan), INDIA \\ *Corresponding author. E-mail: rsmeenaagro@gmail.com
}

Received: July 2, 2014; Revised received: February 13, 2015; Accepted: February 20, 2015

\begin{abstract}
A field study was conducted during rabi seasons of 2008 and 2009 to evaluated of productivity of Indian mustard (Brassica juncea L.) by foliar spray of bio-regulators under different irrigation environments. Amongst treatments, the application of sufficient irrigation water (four irrigations) recorded the highest number siliqua per plant, higher number of seeds per siliqua, 1000 seed weight and yields as compared to all other irrigation treatments. Results show that an increased in seed yield of 92.40 and $39.37 \%$ under sufficient irrigation and limited water condition in 2008 and $93.34 \%$ and $40.31 \%$ in 2009 , respectively over deficient irrigation conditions, foliar sprays of $100 \mathrm{ppm}$ thioglycollic acid at initiation of branching were recorded highest yield attributes and yields. Similarly, 500 ppm of thiourea at initiation of branching and flowering stages also gave second best highest yield attributes and yields as compared to all other bio-regulators spray stages. However, bio-regulators sprays were not recorded any significant effect on oil and protein content. The results were concluded that economic feasibility to improve productivity of Indian mustard with four irrigations levels and sprays of $100 \mathrm{ppm}$ thioglycollic acid and 500 ppm of thiourea at initiation of branching and flowering stages under hyper arid environment.
\end{abstract}

Keywords: Indian mustard, Irrigation, Thiourea, Thioglycollic acid

\section{INTRODUCTION}

Indian mustard (Brassica juncea L. Czernj. and Cosson) is predominantly cultivated in Rajasthan, UP, Haryana, Madhya Pradesh and Gujarat. It is also grown under some nontraditional areas of South India including Karnataka, Tamil Nadu, and Andhra Pradesh. The crop can be raised well under both irrigated and rainfed conditions (DES, 2014). The irrigated area under this crop is $62 \%$ of its total cropped area. General practice of growing this crop is in the fields, which are kept fallow during rainy season to conserve moisture, and farmers also provide one or two irrigation depending on the availability of water even to the crop grown on conserved moisture. The recent research findings indicate the use of bio-regulators for increasing productivity (Hayat and Ahmad, 2007). These bio -regulators acts as chemical catalyst in the plant and improve physiology and reproductive efficiency in the plant. These bio-regulators possibly improve the sucrose transport and increase dry matter partitioning for grain production. Thiourea and thioglycollic acid are such sulphydral bio- regulators. In arid areas, despite constraints imposed by lack of water and high temperatures, the crop plants mostly survive in average rainfall years (Hussain et al., 2010). In view of the above, it is conceivable to assume that if antioxidants are sprayed onto the crop plants, most of the damaging free radicals can be quenched and the crop plants can be able to maintain an improved metabolic energy status, which will then facilitate translocation and partitioning of assimilates for yield formation. Since sulphydryl compounds are strong antioxidants and also supply reactive sulphydryl group for the functioning of sucrose transport protein, they can more effectively improve assimilate partitioning and yield of crops under arid environment (Sharma et al., 2005). Keeping in view the present investigation was conducted to study response of bio-regulators to yield and quality of Indian mustard (Brassica juncea L. Czernj. and Cosson) under different irrigation environments.

\section{MATERIALS AND METHODS}

Experimental site: A field study was conducted during rabi season of 2008 and 2009 on the farm field at Bikaner, Rajasthan, $28^{\circ} 01^{\prime} \mathrm{N}$ latitude and $73^{\circ} 22^{\prime} \mathrm{E}$ longitude at an altitude of 234.70 meters above mean sea level (Arabian sea) under irrigated hyper arid western dry zone of India.

Treatments detail: The experiment was laid out in a split-plot design with 3 levels of irrigation [Water sufficient (four irrigation), water limited (two 
irrigation) and water deficient ( pre sowing irrigation)] in main plots and nine levels [control (water spray), one foliar spray of thiourea $(500 \mathrm{ppm})$ at initiation of branching, two foliar spray of thiourea $(500 \mathrm{ppm})$ at initiation of branching and flowering, one foliar spray of thiourea (1000 ppm) at initiation of branching, two foliar spray of thiourea $(1000 \mathrm{ppm})$ at initiation of branching and flowering, one foliar spray of thioglycollic acid $(50 \mathrm{ppm})$ at initiation of branching, two foliar spray of thioglycollic acid (50 ppm) at initiation of branching and flowering, one foliar spray of thioglycollic acid $(100 \mathrm{ppm})$ at initiation of branching and two foliar spray of thioglycollic acid (100 ppm) at initiation of branching and flowering] of thiourea and thioglycollic acid spray in sub-plots with four replications. Indian mustard cultivar Bio-902 was sown at a spacing of 30 $\mathrm{cm} \times 15 \mathrm{~cm}$ on 24 October in 2007 and 23 October in 2008. Data on various growth and yield attributes, grain and straw yields of mustard were calculated as per the standard procedures (Gomez and Gomez, 1984).

Statistical analysis: The experimental data were analyzed statistically by applying the technique of analysis of variance prescribed for the design to test and conclusions were drawn at 5\% probability levels.

Physico-chemical properties of experimental soil: The soil was loamy sand having $109.50 \mathrm{~kg}$ available nitrogen/ha, $13.91 \mathrm{~kg}$ phosphorus available/ha, 165.0 $\mathrm{kg}$ available potassium/ha, $8.79 \mathrm{ppm}$ available sulphur $\mathrm{pH} 8.35$ and organic carbon $0.059 \%$.

\section{RESULTS AND DISCUSSION}

Successive increase in the levels of irrigation and thiourea and thioglycollic acid spray significantly improved the all yield parameters. Amongst, the four irrigations were significantly improved the number siliqua/plant, siliqua length, seed/siliqua and 1000 seed weight which were significantly higher than all other irrigation environments in Indian mustard, all growth parameters significantly increased with increasing number of irrigations in both the years of field study, respectively. Seed yield significantly increased with each successive increase in irrigation levels upto four in both the years. The response due to four irrigations was $22.18,23.26 \mathrm{q} /$ ha seed yield and $63.33,64.88 \mathrm{q} /$ ha in straw yield was observed over $11.53,12.03 \mathrm{q} / \mathrm{ha}$ seed yield and $25.55,26.57 \mathrm{q} / \mathrm{ha}$ straw in pre sowing irrigation during both the years, respectively (Table 1). Sufficient irrigation may be attributed as more number of branches, longer plants and more yield which consequently helped in the production of higher straw yield and biological yield. The irrigation levels were not recorded any significant effect on oil and protein content (Table 3). Application of four irrigations significantly increased oil yield $(900.26,947.68 \mathrm{~kg} / \mathrm{ha})$ over pre sowing irrigation $(453.77,474.63 \mathrm{~kg} / \mathrm{ha})$ in both the years, respectively. Similarly results observed with four irrigations on protein yield (447.14,
$472-13 \mathrm{~kg} / \mathrm{ha}$ ) over pre sowing irrigation (226.14.77, $237.84 \mathrm{~kg} / \mathrm{ha}$ ) during both the years, respectively. Issa and Sharma (2007) also conducted similarly field studies on Indian mustard with irrigation levels and reported that in two irrigations recorded significantly higher number of silique per plant, increased 1000 grain weight, seed yield, oil yield and protein content over one irrigation and control.

Spray of different bio-regulator treatments significantly influenced the yield attributes, yield and quality parameters of Indian mustard. Foliar sprays of 100 ppm thioglycollic acid at initiation of branching were recorded highest yield attributes, yields, oil and protein yield. Similarly, $500 \mathrm{ppm}$ of thiourea at initiation of branching and flowering stages also gave second best highest yield attributes, yields, oil and protein yield as compared to all other spray stages (Tables 1 and 3). However, thioglycollic acid and thiourea sprays were not recorded any significant effect in oil and protein content. Increased of thiourea spray up to $1000 \mathrm{ppm}$ and thioglycollic acid up to100 ppm at initiation of branching and flowering stages, the pronounced effect of thiourea and thioglycollic acid on growth characters might be attributed due to its more divers biological activities because of its -SH group compounds Sahu et al. (1993). Thiourea with its sulphydral group not only favored larger green photosynthetic surface but it might have also favored the activity of starch syntheses and hence the effective period of filling seeds. Significant increase $(\mathrm{P}<0.05)$ in grain yield with thiourea and thioglycollic acid spray treatment also appears to have resulted via -SH group compound enhanced photosynthetic efficiency and hence large accumulating of photosynthates during seed development. These observations were also supported by the results of Sahu et al. (1993) who observed that bio- regulators spray also improved the seed yield, oil and protein contents in canola. (Iqbal, 1988) reported increased oil and protein yield with bio-regulators spray in canola cultivars. The positive correlation of protein, oil, total sugars and S-containing amino acids was also found in oilseeds.

Interactions: The interaction between thiourea, thioglycollic acid spray and irrigation levels was significant $(\mathrm{P}<0.05)$ on seed yield of Indian mustard (Table 2). Spray levels of thiourea upto $500 \mathrm{ppm}$ and thioglycollic acid $100 \mathrm{ppm}$ at initiation of branching and flowering stages, increase in spray levels significantly increased the seed yield of Indian mustard and thereafter decreased significantly at reducing rate of spray levels of thiourea and thioglycollic acid. Similarly, at the same decreased irrigation levels significantly decreased seed yield up to pre sowing irrigation. The maximum seed yield was in treatment combination four irrigation levels and thioglycollic acid 100 ppm spray at initiation of branching and flowering stages during both the years, respectively. Although different irrigation levels and bio-regulator treatments independently brought significant increase in growth and yield attributes but 
R. K. Dadhich et al. / J. Appl. \& Nat. Sci. 7 (1) : 52 - 57 (2015)

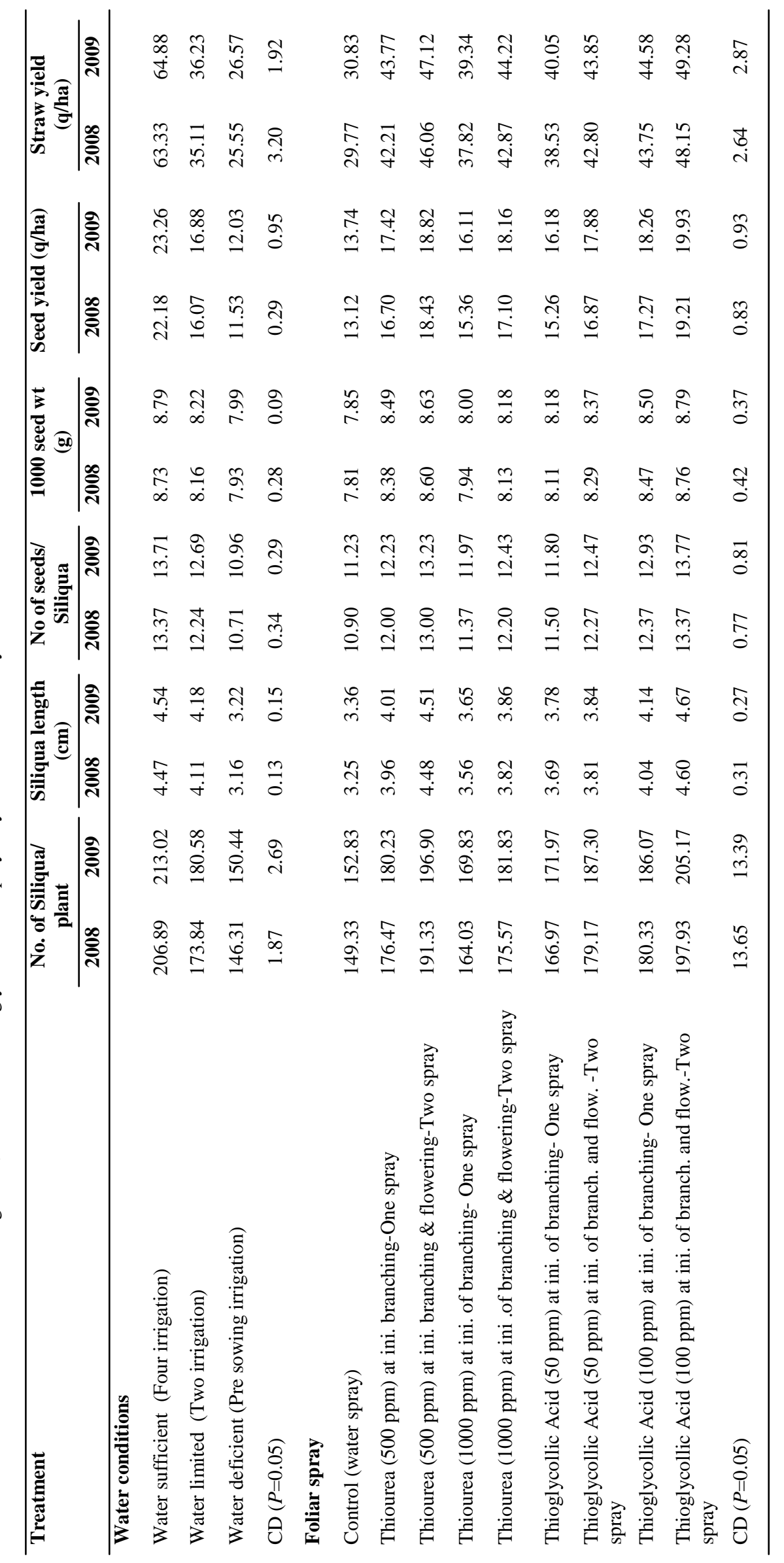


R. K. Dadhich et al. / J. Appl. \& Nat. Sci. 7 (1) : 52 - 57 (2015)

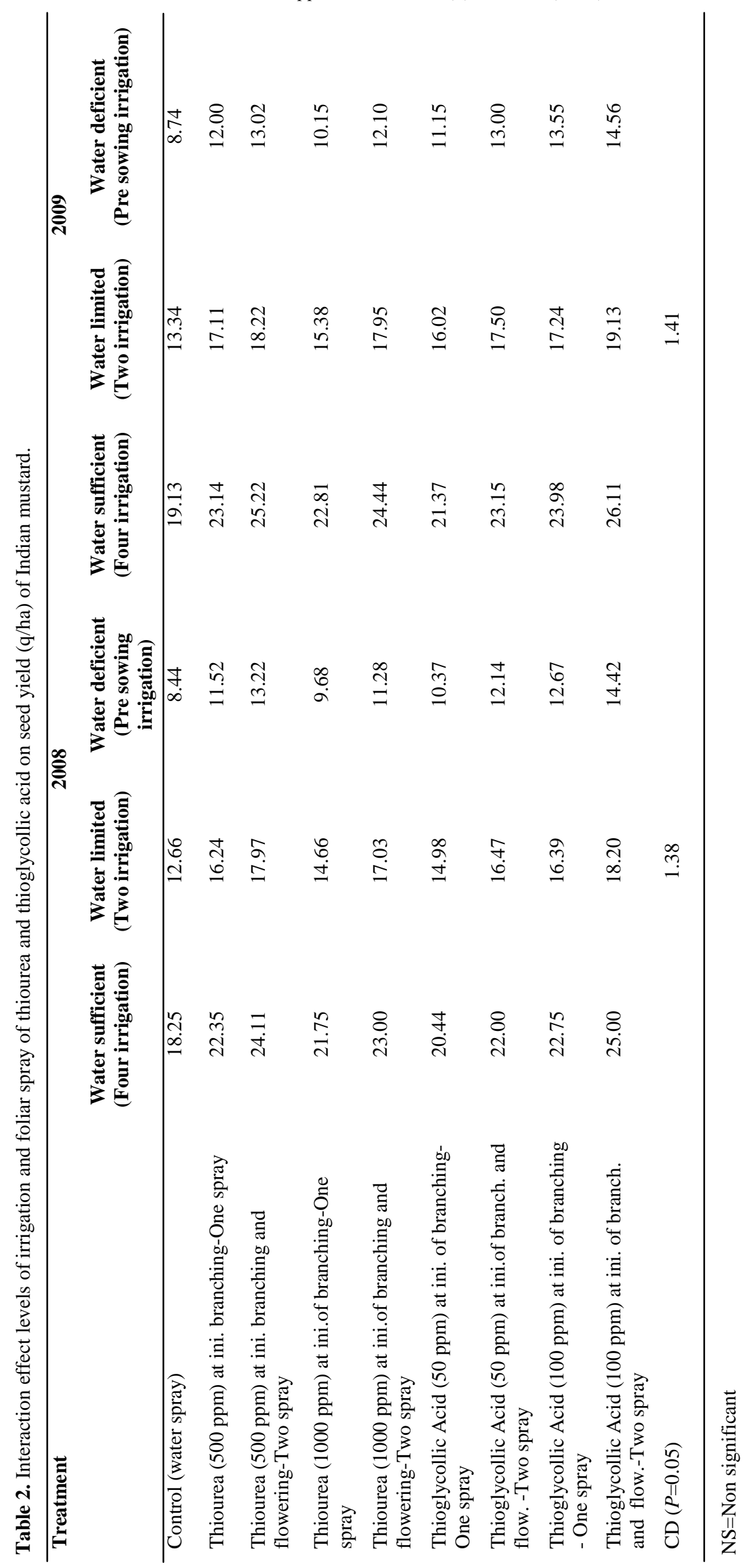


R. K. Dadhich et al. / J. Appl. \& Nat. Sci. 7 (1) : 52 - 57 (2015)

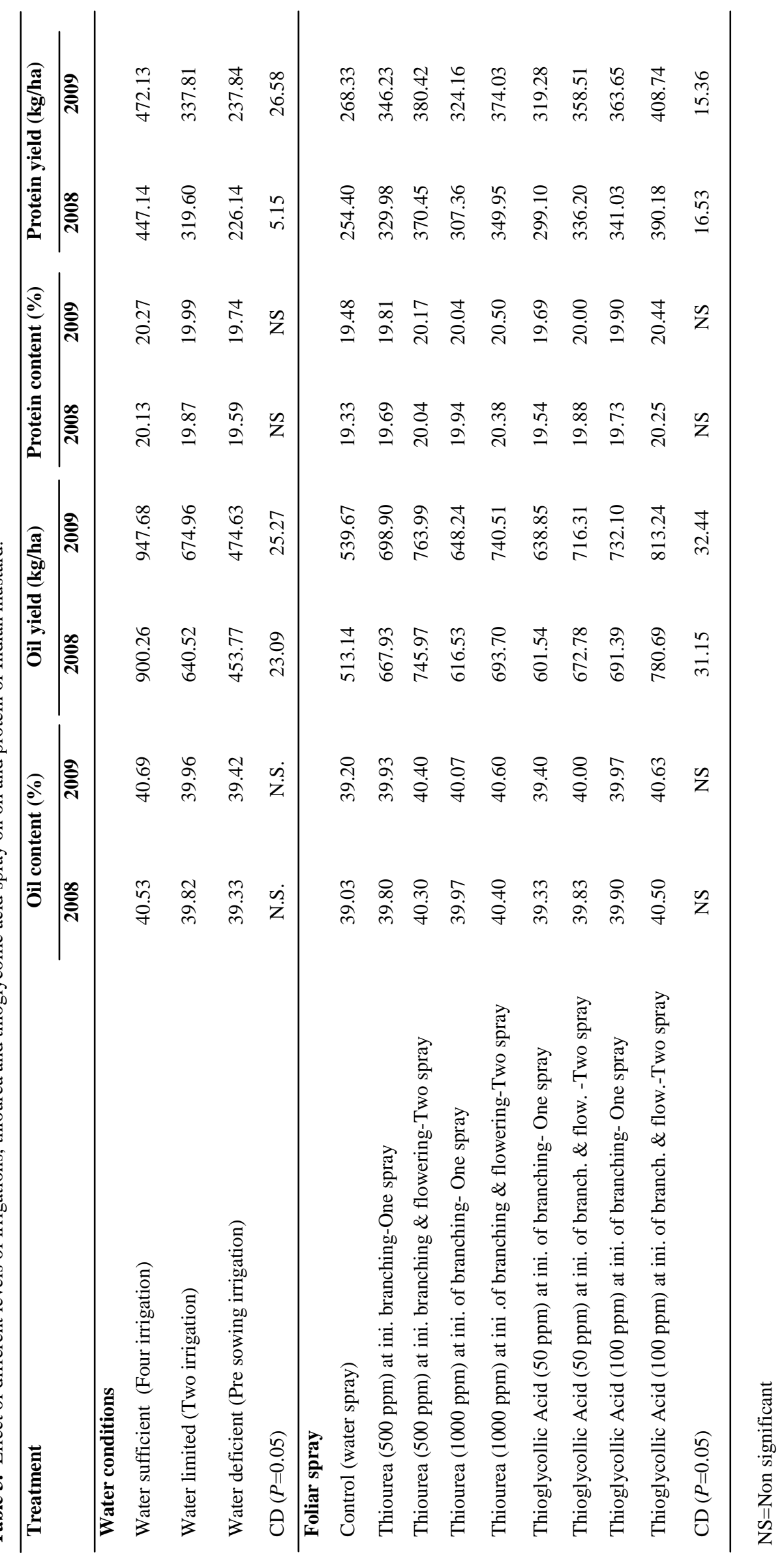


interaction of both showed that response of irrigation levels were governed by thiourea and thioglycollic acid vice versa exhibiting their interdependence for obtaining higher value of these parameters showed the positive response regarding seed yield as obtained in the present study. Higher irrigation frequency increased the availability of nutrients and thus enhanced the uptake of nutrient which consequently improved the crop seed yield. Similarly, the pronounced effect of thiourea and thioglycollic acid on growth characters might be attributed due to improved photosynthetic efficiency of plant there by overall improvement in growth and yield attributes. Similar findings had been reported by Dadhich and Meena (2014) and observed that spray of bio-regulators significantly increased all growth parameters of Indian mustard. Anitha et al. (2006) conducted an experiment on horse gram with bio-regulators spray and reported that higher yield attributes, yield and number of quality parameters were observed over control and Garg et al. (2006) also reported similar trend in cluster bean.

\section{Conclusion}

In conclusion, foliar spray of thiourea up to $500 \mathrm{ppm}$ and thioglycollic acid $100 \mathrm{ppm}$ at initiation of branching and flowering stages indicated its economic feasibility to improve productivity of Indian mustard with four irrigations. Thus, it can be potential alternative to increase Indian mustard production under hyper arid environment.

\section{REFERENCES}

Anitha, S., Purushothaman, S.M. and Sreenivasan, E. (2006). Response of Horse gram (Macrotyloma uniflorum LAM.) to thiourea application under rainfed condition. Legume Research. 29 (2): 146-149.
DES, (2014). Directorate of Economics and Statistics, Department of Agricultural and cooperation Ministry of Agriculture, Government of India. Agricultural Statistics at a Glance. pp. 86-98.

Garg, B.K., Barman, U. and Kathju, S. (2006). Influence of thiourea on photosynthesis, nitrogen metabolism and yield of cluster bean (Cyamopsis teragonoloba L.) under rainfed condition of Indian arid zone. Plant Growth Regulation, 48: 237-245.

Gomez, K.A. and Gomaz, A.A. (1984). Statistical Procedures for Agricultural Research. John Wiley \& Sons, Singapore.

Hayat, S. and Ahmad, A. (2007). Salicylic Acid: A Plant Hormone. Springer Publishers, Dordrecht, the Netherlands Pp 1-371.

Hussain, M., Farooq, M., Jabran, K. and Wahid A. (2010). Foliar application of glycinebetaine and salicylic acid improves growth, yield and water productivity of hybrid sunflower planted by different sowing methods. Journal of Agronomy and Crop Science. 196(2): 136-147

Iqbal, J. (1988). Effect of applied sulphur on yield and quality to Brassica juncea (Raya Pila). MSc Thesis Dept Soil Science, University of Agriculture Faisalabad.pp26-34.

Issa, P.W. and Sharma, S.N. (2007). Effect of sulphur on yield attributes and yield of Indian mustard (Brassica juncea) as influenced by irrigation. Indian Journal of Agricultural Sciences, 77(3): 7188-90.

Sahu, M.P., Solanki, N.S. and Dashora, L.N. (1993). Effect of thiourea, thiamin and ascorbic acid on growth and yield of maize (Zea mays L.). Journal of Agronomy and Crop Science. 171: 65-69.

Sharma, G., Sutaliya, R., Singh, J. and Sharma K.P. (2005). Production potential and economic return of mustard [Brassica juncea (L.) Czern \& Coss] and linseed (Linum usitatissimum L.) intercropping systems under irrigated condition. Crop Research, 30(3): 483-5.

Dadhich, R.K. and Meena, R.S. 2014. Performance of Indian mustard (Brassica juncea L.) in response to foliar spray of thiourea and thioglycollic acid under different irrigation levels. Indian Journal of Ecology, 41 (2): 376 - 378. 